\title{
Data: The New Currency of The Digital World and the Race among Nations to Protect Data
}

\author{
S. Prasad, A. Paul Williams.
}

\begin{abstract}
This article focuses on the significance of the data with the advancements in the technology and its consequent implications on various sectors. With nations around the world and especially India concentrating on digitalizing all the aspects of life, it is important to secure the data that will be created because of its digitalization. India's flagship program DIGITAL INDIA makes it evident how important is digitalizing for the welfare of the nation. The article has described the importance of data analyzing in maximizing the efficiency, profitability, the productivity of companies and also how it helps the Government with good Governance by reducing the leakages in subsidy transfer, identifying the beneficiaries of the welfare schemes, etc. Another aspect regarding climate modelling and weather prediction, which was made possible because of the availability of the data also has been described. Finally, how countries are trying to safeguard the domestically generated data in the form of regulations such as the General Data Protection Regime of the European Union are also discussed. Eventually, it also proposes how the various stakeholders should come in together and resolve the differences among them for the greater good of the people around the globe.
\end{abstract}

Keywords: Industrial revolution 4.0, Data analytics and prediction, Sustainable Development, GDPR.

\section{INTRODUCTION}

Data is gaining importance because of the technological advancements that are happening around us. The most important is the Industrial Revolution 4.0, which is about Artificial Intelligence. The concept of Artificial Intelligence is about a machine functioning like the neurons of a human being thereby able to think and decide like a human. Even before this Industrial Revolution 4.0, the significance of the data cannot be questioned. It has eased many complex processes such as census, documentation, etc. It helped in storing and analyzing complex information and thereby making the decision-making process a cake walk. It has revolutionized almost every field that is known to humanity. With the evolution of technology, the utility of data has increased manifold. Let us discuss how the data plays an important in a wide variety of sectors.

Revised Manuscript Received on July 25, 2019.

S. Prasad, Assistant Professor, Dept of International Business, Alagappa University, Karaikudi, Tamilnadu, India.

Email ID: prasadselvaraj@gmail.com (Ph:9790592686)

A. Paul Williams, Ph.D. Scholar, Dept of International Business, Alagappa University, Karaikudi, Tamilnadu, India.

Email ID: williamspaul333@gmail.com (Ph:7094352569)

\section{DATA, THE BUSINESS ENABLER}

The companies which have abundant data can use it for the better internal management of the company resources be it the material, human, or whatever resources thereby eliminating the wastage of resources and also increase the efficiency and productivity of the company. Also, the competitiveness of the company can be increased when it has a better hold on the market data. This data can be used by the companies to predict the market sentiment, thereby thinking way ahead of its competitors. Example, the companies such as the Amazon, Uber, Ola, and many others are using the data about the user preference and with the time being, they can predict the customer. Hence the user interface is made easy, and the customers will be satisfied when the process involved is made simple.

\section{GOVERNANCE MADE SIMPLER}

The Government is also concentrating on processing and analyzing the enormous amount of data it receives and uses it for better Governance of the country. It is useful in identifying the beneficiaries of welfare programs of the Government. Also, the leaks in the Government programs can be minimized if the weak spot in the supply chain is identified. The Government is also implementing the Public Financial Management System wherein the fund flows to different projects are monitored by the PMO (Prime Minister's Office). This will ensure transparency in Governance. Another important aspect is regarding the effectiveness of the subsidies, and the Government gives to the citizens. With proper data, we can identify the reality that exists in Society. This will lead to appropriate channelization from resources to the needy strata of the Society.

\section{HEALTHY DATA FOR A HEALTHY SOCIETY}

The health sector is the most significant beneficiary. This is because with the predictive analytics, the responsible genes can be identified and if possible in future gene editing can be done to reduce the incidence of the disease. At least by identifying the risk factors, the doctors can advise the disease-prone patient to take precautionary measures, which will help prevent the disease at the right time. With proper data on the incidence of epidemics on population and the nature/mode of impact, the geography, concerned authorities can take necessary steps in preventing the outbreaks. 


\section{CLIMATE MODELLING AND WEATHER FORECASTING}

Farmer suicides and farmer distress is the most often news we hear in the news channel and newspapers, with ample data and proper analyzing techniques the Government can identify the problematic areas in the farming and take necessary steps to bring the agriculture sector out of the crisis. It can also help in identifying better management practices in the application of pesticides, soil nutrients, and irrigation practices. The data enables the meteorologist to better predict the weather systems because of the historical information that is available with them. With this prediction, the planning of the Government will be more productive, since most of the Indians depend on agriculture. The planning in the case of disaster management is an essential factor to be considered when it comes to the welfare of the Society. Take the example of the recent cyclone Fani which hit the Odisha Coast, with better knowledge on the weather systems, and the authorities were able to take precautionary, resettlement and rehabilitation measures properly.. were able to take precautionary, resettlement and rehabilitation measures properly.

\section{SUSTAINABLE DEVELOPMENT}

Nowadays, people around the world are focusing on sustainable development wherein the developmental need of the present is not affecting the resources for the future. So to achieve this sustainable development, the data on the availability of the resources will help the academicians and the researchers to identify how these resources can be optimally used, thereby eliminating their threat of existence shortly. Climate change and its implication on the environment is another primary global debate. With emerging technology and climate prediction system, the risks associated with the global warming have been easily identified, and the United Nations and the Governments all over the world are taking steps to reduce the greenhouse gas emissions. This will lead to reduced global warming. This is evident from the Paris Agreement of 2015, wherein the nations obliged to Intended Nationally determined Contributions towards reducing global warming by $1.5^{\circ} \mathrm{C}$ to pre-industrial levels by 2050 starting from 2020.

\section{DATA REGULATION AND ITS IMPLICATION}

With the concerns surrounding the privacy of the individual in the era of digitalization, the Governments all around the world are concerned about their private data. The European Union's General Data Protection Regime (GDPR) is the frontrunner in the concept of data protection and data localization. It also briefs about how the companies have to obtain permission if has to use the data outside the EU. With the recent Supreme Court's ruling in the Puttasamy case where Right to Privacy was declared as a fundamental right under Article 21 of the Indian Constitution, which talks about the Right to Life, the Government was quick enough to realize the importance of the issues surrounding the data localization. It constituted the Justice B,N. Srikrishna Committee to look into the problems of data localization. It recommended data mirroring wherein a copy of the data can be transferred to the offshore locations, and the original copy has to be stored in the territory of India. Also, it gave some guidelines regarding the storage and the time limit that has to be adhered by the Multinational Conglomerates. Some argue that it might hinder the ease of doing business in India. Also, the operational costs of the company will increase because of establishing the infrastructure and other means to store and process the data locally. But considering the National Security the Government has considered this step because whenever there is a need to access the data, the Government has to use the provisions under Mutual Legal Assistance Treaty (MLAT) which is cumbersome and time-consuming. Also, when the servers are located locally, the needs of the country can be dealt with effectively and according to the terms and conditions of our own. Also recently there was an internal disturbance in some districts of Tamilnadu and the Government has to impose section 144 of IPC to restore normalcy and it took around one week to narrow down to the culprits. This would have been made easier when the data and the server is localized.

\section{CONCLUSION}

With the worthiness of the data getting realized in unimaginable ways in the recent days of technological development, the national Governments and the Multinational companies are also obsessed with the Data protection and Data trading. Hence both the public and private players should come together and try to resolve their differences, thereby securing the privacy of the people across the world. Sometimes this is the most valued resource of a country. Hence due diligence has to be given when handling issues related to the data.

\section{ACKNOWLEDGMENT}

Both of us would like to thank the organizing secretary Dr.P.S. Nagarajan, Assistant Professor, Alagappa Institute of Management for conducting the conference on Online marketing spree which gave us the exposure to wide array of ideas. Also, both the authors would like to thank the MHRD for the innovative scheme RUSA 2.0 which gave an immense financial support to pursue research in the field of social science.

\section{REFERENCES}

1. https://www.thequint.com/news/india/key-highlights-from-srikrishnacommittee-report-on data-protection last accessed on 15/05/2019.

2. https://economictimes.indiatimes.com/news/politics-and-nation/justic e-bn-srikrishna-committee-submits-report-on-data-protection-herere-t he-highlights/articleshow/65164663.cms last accessed on 13/05/2019.

3. https://www.ncdc.noaa.gov/data-access/model-data/model-datasets last accessed on 13/05/2019. 


\section{AUTHORS PROFILE}

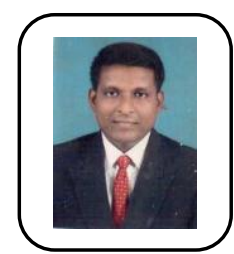

Dr.S.Prasad MBA, MHRM, M.Com, Ph.D an Assistant Professor in the Department of International Business, Alagappa University, Karaikudi has presented 40 research papers in national and international conferences and has published 20 articles in reputed international journals. His expertise is in the field of Port Management, Marketing and Human Resource Management. Also he has done a project on export performance of spices in India funded by Alagappa University Research Fund. His research interests include Foreign Exchange Management, International Marketing and International Economics

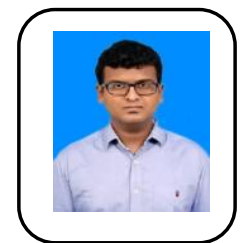

A. Paul Williams is a Mechanical Engineer and he did his under-graduation from College of Engineering, Guindy. He got state $3^{\text {rd }}$ in the minorities category in Tamilnadu HSC examination. After completing his masters in management, currently he is pursuing Ph.D in the Department of International Business. He qualified the NET examination in his first attempt. His research is in field of Foreign Exchange Management and International Economics. $\mathrm{He}$ has also successfully organized a "FIVE DAY WORKSHOP ON RESEARCH METHODOLOGY AND DATA ANALYSIS" sponsored by RUSA 2.0 Scheme of MHRD. 